\title{
Latitudinal land-sea distributions and global surface albedo since the Cretaceous
}

\author{
D.V. Kent ${ }^{\text {a,b, }}$, G. Muttoni ${ }^{\mathrm{c}}$ \\ ${ }^{a}$ Lamont-Doherty Earth Observatory of Columbia University, Palisades, NY 10964, USA \\ ${ }^{\mathrm{b}}$ Earth and Planetary Sciences, Rutgers University, Piscataway, NJ 08854, USA \\ ' Dipartimento di Scienze della Terra 'Ardito Desio', Università degli Studi di Milano, via Luigi Mangiagalli 34, I-20133, Milan, Italy
}

\section{A R T I C L E I N F O}

\section{Editor: Paul Hesse}

\section{Keywords:}

Paleogeography

Early Eocene climate optimum

Late Cenozoic Ice Age

\begin{abstract}
A B S T R A C T
We estimate global surface albedo from the areal proportion of land to sea in climatically-significant latitudinal belts at ten million-year intervals for the Late Cretaceous and Cenozoic (120 million years ago to Present) using modern plate tectonic reconstructions and a composite apparent polar path designed to minimize known biases in the determination of paleolatitude. We find that global surface albedo stayed almost constant until it shifted $30 \%$ higher to the modern value of around 0.15 with the inception of the Late Cenozoic Ice Age 34 million years ago, reflecting polar ice-albedo amplification of global cooling resulting from the reduction of greenhouse gases below a critical threshold, most probably as the culmination of enhanced $\mathrm{CO}_{2}$ weathering consumption of continental mafic rocks in the tropical humid belt. The contribution from cloud cover toward a planetary albedo is unclear in the absence of measurable proxies but might eventually be gauged from the role cloudiness evidently plays in maintaining radiative balance with the increasing land bias between northern and southern hemispheres over the Cenozoic.
\end{abstract}

\section{Introduction}

Standard solar models (Feulner, 2012) show only a gradual increase in solar luminosity, ramping up to only about $2 \%$ over the Mesozoic and Cenozoic (since $250 \mathrm{Ma}$ ), which combined with a constant modern planetary albedo of around $30 \%$ that is typically assumed in climate models (e.g., Foster et al., 2017), leaves radiative forcing from varying concentrations of atmospheric carbon dioxide $\left(\mathrm{pCO}_{2}\right)$, the most important noncondensing greenhouse gas (Lacis et al., 2010), as the primary means for explaining large shifts in global climate such as the Late Cenozoic Ice Age that punctuated the predominantly equable (nonglacial) climate of the Mesozoic and Cenozoic to that point (Crowley and Berner, 2001). In the widely used GEOCARB family of carbon cycling models (e.g., Berner, 1991; Berner, 1994; Berner, 2006; Berner and Kothalava, 2001), atmospheric $\mathrm{pCO}_{2}$ concentrations reflect negative feedbacks, chiefly temperature-dependent silicate weathering (Berner et al., 1983; Walker et al., 1981), that act to stabilize global temperatures in response to presumed variable tectonic outgassing of $\mathrm{CO}_{2}$. Weathering sinks of $\mathrm{CO}_{2}$ may also have varied independently as continental landmasses and arc-continent collisions drifted across climatic zones, especially alkaline-rich basaltic rocks in the potent tropical humid belt for weathering (Goddéris et al., 2008; Goddéris et al., 2014; Jagoutz et al., 2016; Kent and Muttoni, 2008, 2013; Macdonald et al., 2019), allowing Earth to bypass the Walker feedback thermostat and occasionally descend into glacial modes of varying duration and severity (Donnadieu et al., 2004).

In support of the $\mathrm{CO}_{2}$ paradigm, atmospheric $\mathrm{pCO}_{2}$ concentrations based on proxy data broadly covary with paleotemperature estimates, suggesting an equilibrium climate sensitivity of $\sim 3{ }^{\circ} \mathrm{C}$ for doubling of $p \mathrm{CO}_{2}$ over the Cenozoic (past $66 \mathrm{Myr}$ ) (Hansen et al., 2008; Hansen et al., 2013; PALAEOSENS, 2012). The $p \mathrm{CO}_{2}$ proxy data derived from geological recorders like fossil plant stomata, paleosols, phytoplankton, boron isotopes, and mineral phases have large uncertainties (Royer, 2014) but show a general correlation with bottom water temperatures and sea levels (Fig. 1) all being generally high during warm periods such as the Cretaceous thermal maximum (CTM, $\sim 90$ million years ago, or $\mathrm{Ma}$ ) and the Early Eocene climate optimum (EECO, $\sim 50 \mathrm{Ma}$ ) (Jagniecki et al., 2015), consistent with negligible polar ice sheets (Pross et al., 2012), and all becoming lower with the dramatic shift to polar glacial conditions at $34 \mathrm{Ma}$ (Eocene-Oligocene transition, EOT) in Antarctica (DeConto et al., 2008; Katz et al., 2008; Liu et al., 2009; Pagani et al., 2011; Tibbett et al., 2021) as well as the northern hemisphere based on

\footnotetext{
* Corresponding author at: Lamont-Doherty Earth Observatory of Columbia University, Palisades, NY 10964, USA.

E-mail addresses: dvk@ldeo.columbia.edu (D.V. Kent), giovanni.muttoni1@unimi.it (G. Muttoni).
} 


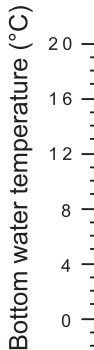

A)

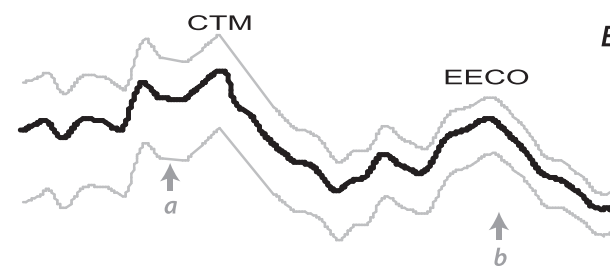

EOT<smiles>C1=[Te]C[CH-]1</smiles>

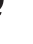

Fig. 1. Trends in global climate since 120 Ma based on (A) bottom water temperatures from oxygen isotopes and (B) reconstructed sea levels (modified from Kent and Muttoni (2013) with data from Cramer et al. (2011) smoothed to emphasize variations on $>5 \mathrm{Myr}$ timescales). CTM is Cretaceous thermal maximum, EECO is early Eocene climatic optimum, MMCO is middle Miocene climatic optimum, EOT is EoceneOligocene Transition to Late Cenozoic Ice Age with major sea-level drop at the inception of Antarctic glaciation, and $\boldsymbol{Q}$ is beginning of Quaternary with sealevel drop at the intensification of Northern Hemisphere glaciation. Labels a) to d) refer to continental reconstruction panels in Fig. 3.

ice-rafting in Norwegian-Greenland Sea sediments (Eldrett et al., 2007). However, changes in combined net radiative forcing from $\mathrm{pCO}_{2}$ and solar radiance apparently explains only about one-half of major climate shifts exemplified by the Late Cenozoic Ice Age (Crowley and Berner, 2001).
Albedo, an outstanding key factor in the radiation balance controlling climate (Henderson-Sellers and Wilson, 1983), is difficult to gauge in the geologic record in the absence of a good proxy for cloud cover, which today doubles Earth's clear sky or global surface albedo $\left(R_{s}\right)$ from 0.15 as measured and calculated (Robock, 1980) to a planetary albedo
A

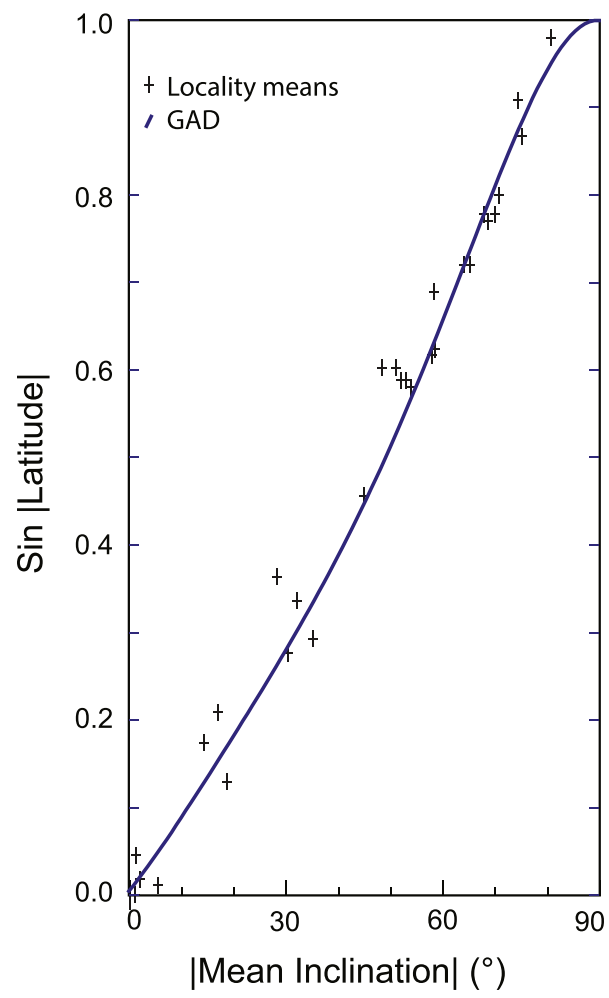

B

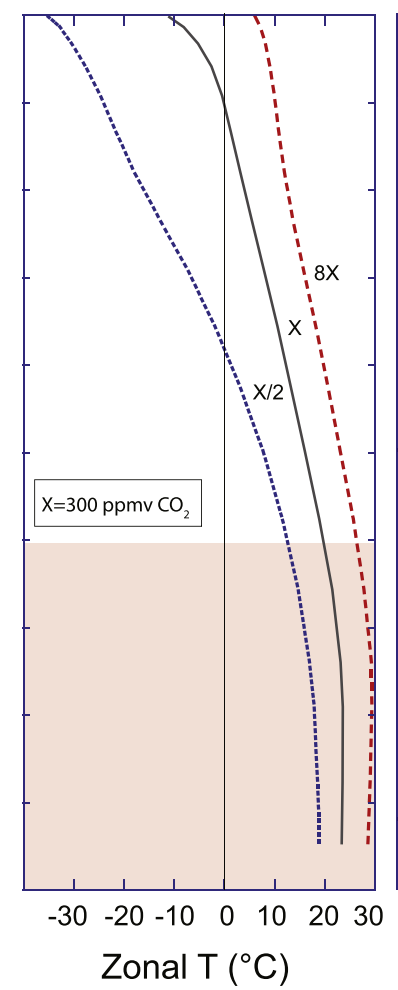

C

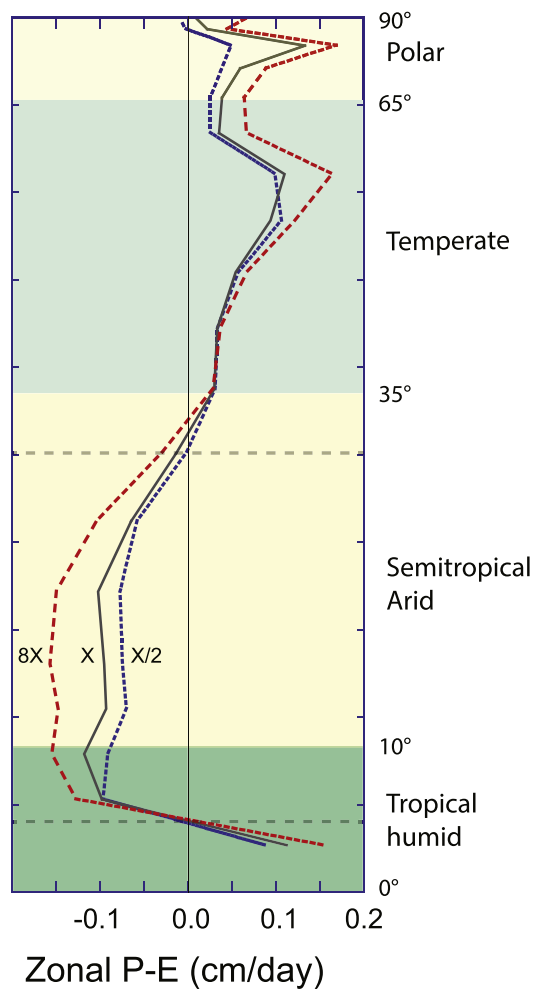

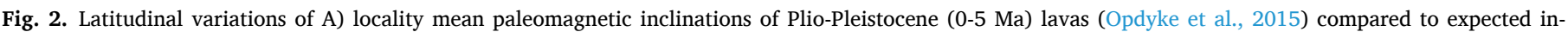

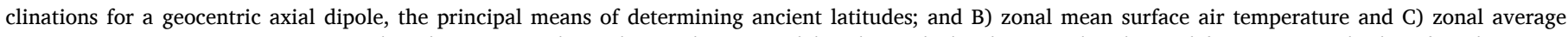

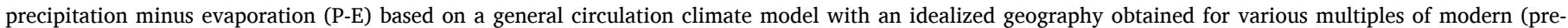

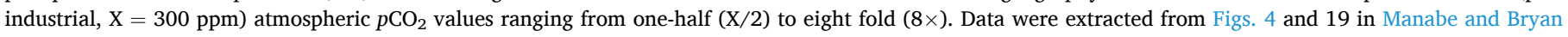

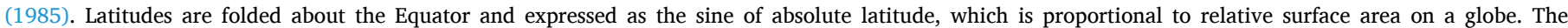

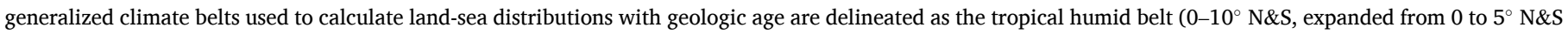

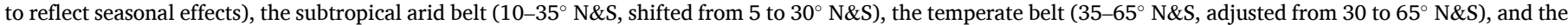

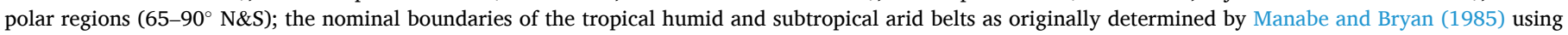

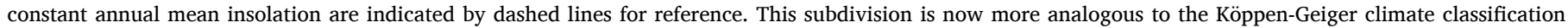
based on instrumental station records of seasonal temperature and precipitation fluctuations (Peel et al., 2007). 
$\left(R_{p}\right)$ of 0.29 as can be observed by satellites (Stephens et al., 2015). Earth's average surface temperature today from the combined effects of greenhouse warming and planetary albedo (at current solar luminosity) is about $15{ }^{\circ} \mathrm{C}$, which would be much lower (about $-20{ }^{\circ} \mathrm{C}$ ) in the absence of greenhouse gases in the atmosphere (Lacis et al., 2010) and would drop to below $-40{ }^{\circ} \mathrm{C}$ if Earth suddenly became completely icecovered with a high planetary albedo $\mathrm{R}_{\mathrm{p}} \sim 0.6$ (Hoffman and Schrag, 2002).

The low reflectivity of oceans, which absorb much of the insolation received by Earth's surface, suggests that estimating changes in land-sea distributions across latitudinal belts with plate tectonic motions may provide useful constraints on long-term changes in albedo. An early analysis of the latitudinal dependence of surface albedo since the beginning of the modern plate tectonic regime at $\sim 180$ Ma found that the greatest increases in the fraction of land occurred in the latitude belt $\left(10-30^{\circ} \mathrm{N}\right)$ that is associated with desert regions with high surface albedos (Barron et al., 1980). This change in land area was thought to have contributed to long-term cooling even though a planetary albedo model with present-day cloud cover subsequently indicated that the warm Cretaceous climate at $\sim 100$ Ma may have been maintained by a global mean absorbed solar radiation a few percent higher than today even with snow and sea ice prescribed for latitudes higher than $\sim 60^{\circ}$ (Thompson and Barron, 1981). Additional forcing factors such as oceanographic gateways (Kennett, 1977), the geometry of land-sea contrasts driving potential changes in the redistribution of heat seasonally (Donnadieu et al., 2006) and especially changes in atmospheric $p \mathrm{CO}_{2}$ (Berner, 1990) have also long been called upon to help explain the climate record, especially for the culminating cooling trend in the Cenozoic (Barron, 1985).

Plate tectonic models and critical paleomagnetic constraints for determining latitude have become considerably more refined and allow more precise and accurate estimations of latitudinal land-sea distributions. In a recent study of $\mathrm{CO}_{2}$ consumption from silicate weathering potential, we estimated land area in the potently hot tropical humid belt $\left(5^{\circ} \mathrm{S}\right.$ to $\left.5^{\circ} \mathrm{N}\right)$ from $120 \mathrm{Ma}$ to the Present (Kent and Muttoni, 2013). Here we extend that analysis to estimate land-sea distributions and the inferred surface albedos in climate belts extending to the poles (Fig. 2). Delineation of these climate belts was again guided by the latitudinal variation in available moisture (precipitation minus evaporation, P-E) in the context of the Equator to pole temperature $(\mathrm{T})$ gradient in a general circulation model with an idealized geography for various multiples of atmospheric $p \mathrm{CO}_{2}$ (Manabe and Bryan, 1985). However, we shifted the nominal latitudinal boundaries of the P-E climate belts a few degress to take into account seasonal variations, such that the tropical humid belt becomes $10^{\circ} \mathrm{S}$ to $10^{\circ} \mathrm{N}$, more comparable in its greater width with more recent climate modeling (e.g., Burls and Fedorov, 2017), so that the subtropical arid belts are now configured to extend from 10 to $35^{\circ}$, the temperate belts from 35 to $65^{\circ}$ and the polar belts remain $65-90^{\circ}$ in latitude all both in the northern and southern hemispheres. These belts loosely correspond to Köppen-Geiger climate classifications A (tropical), B (arid), C (temperate) and D-E (cold-polar), respectively, which are defined by temperature and precipitation limits from modern station measurements (e.g., Peel et al., 2007). Independent determination of latitudes of the mobile continents is critical, especially with the sharp boundaries of significant climate belts, and must be accomplished using time-averaged paleomagnetic data deemed most representative of the geocentric axial dipole field (Tauxe, 2005) (Fig. 2).

\section{Methods}

Albedos for different surfaces are essentially those used by Barron et al. (1980) for ready comparison of results. The various climate zones, their percentages of Earth's surface area $\left(510 \mathrm{Mkm}^{2}\right.$ with $29 \%$ or 150 $\mathrm{Mkm}^{2}$ land and $71 \%$ or $360 \mathrm{Mkm}^{2}$ ocean, as at present) and the expected variations in surface albedo $\left(\mathrm{R}_{\mathrm{s}}\right)$ within each zone are as follows.
- Tropical humid belt: expanded from 0 to $5^{\circ} \mathrm{N} \& S$ (Manabe and Bryan, 1985) to $0-10^{\circ} \mathrm{N} \& S$ to account for seasonal variations. The broader latitudinal range broadly corresponds to Köppen-Geiger climate classification A (tropical) but is here characterized following Manabe and Bryan (1985) by high relative T and P > E (Fig. 2). The tropical humid belt encompasses $17.4 \%$ of Earth's surface area and is expected to have a narrow range of surface albedos from only $\sim 0.06$ (ocean) to 0.10 (tropical forest) with modest seasonal variation (Kukla and Robinson, 1980; Robock, 1980).

- Subtropical arid belts: shifted from 5 to $30^{\circ} \mathrm{N} \& \mathrm{~S}$ (Manabe and Bryan, 1985) to $10-35^{\circ} \mathrm{N} \& S$ to account for seasonal variations, and broadly corresponding to Köppen-Geiger climate classification B (arid), as exemplified in today's world by the low precipitation thresholds delineating the Sahara Desert and the Sahel transition along the southern border, and characterized here by high relative $\mathrm{T}$ and $\mathrm{P}<\mathrm{E}$. Subtropical arid belts as defined encompass $40.0 \%$ of Earth's surface area and can have a wide range of surface albedos from ocean (0.06) to deserts (0.35) depending on the land-sea distribution.

- Temperate belts: compressed somewhat from 30 to $65^{\circ} \mathrm{N} \& \mathrm{~S}$ (Manabe and Bryan, 1985) to $35-65^{\circ} \mathrm{N} \& \mathrm{~S}$ that broadly correspond to Köppen-Geiger climate classification C (temperate) with a range of seasonal temperature and precipitation conditions and here identified following the model of Manabe and Bryan (1985) by moderate $\mathrm{T}$ and P $>$ E. The temperate belts encompass $33.3 \%$ of Earth's surface area but are expected to have a narrow range of surface albedos from ocean ( $R_{S}$ ranging to $\sim 0.10$ with lower solar zenith angles) to coniferous and deciduous forests $\left(R_{s}=0.15\right)$ (Kukla and Robinson, 1980; Robock, 1980).

- Polar regions: $65-90^{\circ} \mathrm{N} \& S$ that broadly correspond to combined Köppen-Geiger climate classifications D and E (cold and polar) with generally low T and variable P-E, encompassing only 9.4\% of Earth's surface area, by far the smallest in area of the bihemispheric climate belts. Prior to the EOT at $34 \mathrm{Ma}$, polar regions supported warmadapted flora and fauna (e.g., Eberle and Greenwood, 2012), which imply there was little permanent or even seasonal snow or ice cover, so that the average surface albedo was perhaps similar to coniferous forests or low solar zenith oceans $\left(R_{s}=0.15\right)$. After the EOT at $34 \mathrm{Ma}$, the onset of continental glaciation of Antarctica and the likely presence of highly reflective sea ice and snow cover and eventually an ice sheet on Greenland (Eldrett et al., 2007) imply a marked increase in surface albedo in the polar regions, which we assign $R_{s}=0.6$ as estimated for an annual average with solar radiation weighting at $75^{\circ} \mathrm{N} \& S$ today (Robock, 1980).

We use the same tectonic reconstruction parameters and inventory of paleomagnetic reference poles as described earlier (Kent and Muttoni, 2013) to extend globally the analysis of land-sea distributions from the tropical humid belt to $120 \mathrm{Ma}$. The fraction of land area within each of the seven climate belts was estimated in each $10 \mathrm{Myr}$ time interval using a routine in the PaleoMac application (Cogné, 2003). Total global land areas for each reconstruction are typically within a few $\mathrm{Mkm}^{2}$ of today's nominal total land area of $149 \mathrm{Mkm}^{2}$ (Table S1) with smaller continental elements not taken into account, suggesting that uncertainties are generally on the order of a few percent and perhaps higher for some climate belts and time intervals but of little consequence to the overall results. Although there is presently about a 2:1 ratio of land area between the Northern and Southern Hemispheres, the climatological significance of this asymmetry is unclear so in the conceptual spirit of the idealized general climate model of Manabe and Bryan (1985), we combine the land-sea estimates in the four climate belts from each hemisphere to produce land-sea estimates in a total of four bihemispheric climate belts encompassing the entire globe for each reconstruction. We return to the hemispheric land-sea asymmetry at the end of our analysis. 


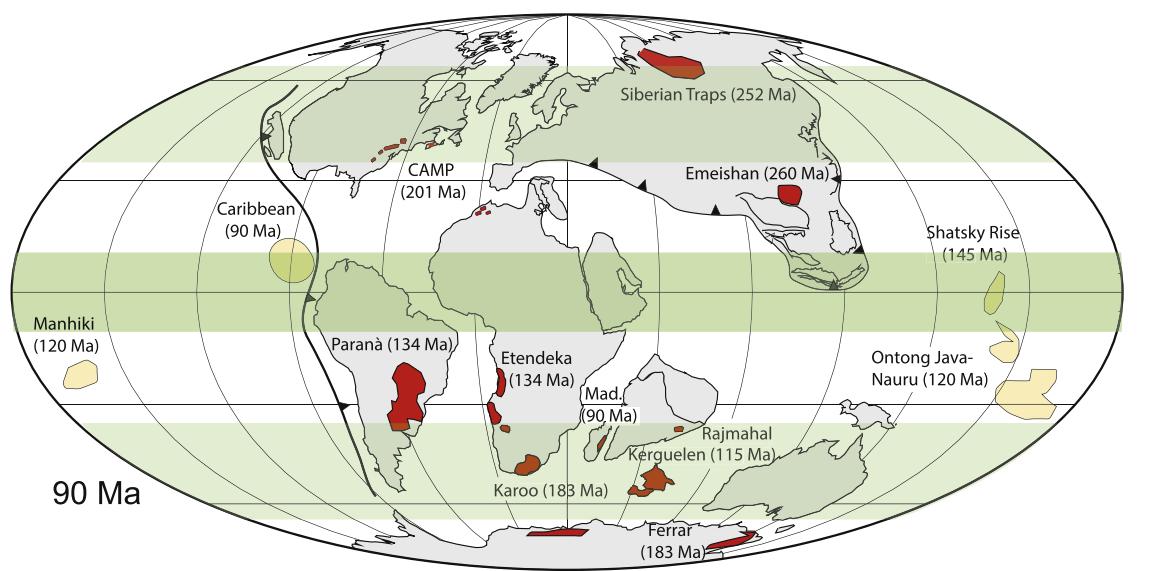

Fig. 3. Representative paleogeographic reconstructions based on the composite apparent polar wander path and finite rotation poles for the major continents from Kent and Muttoni (2013) and used here to estimate land-sea area distributions in idealized climate belts (see Fig. 2). (a) 90 $\mathrm{Ma}$, and (b) $50 \mathrm{Ma}$, are prior to the Eocene-Oligocene Transition to the Late Cenozoic Ice Age at $34 \mathrm{Ma}$, and (c) $30 \mathrm{Ma}$ and (d) $0 \mathrm{Ma}$, are afterwards; see Fig. 1 for climatic context. Large continental basaltic provinces are shown in red, large submarine basaltic provinces in yellow. Paleogeographic maps in full-globe Mollweide projections were made with PaleoMac software (Cogné, 2003). (For interpretation of the references to colour in this figure legend, the reader is referred to the web version of this article.)
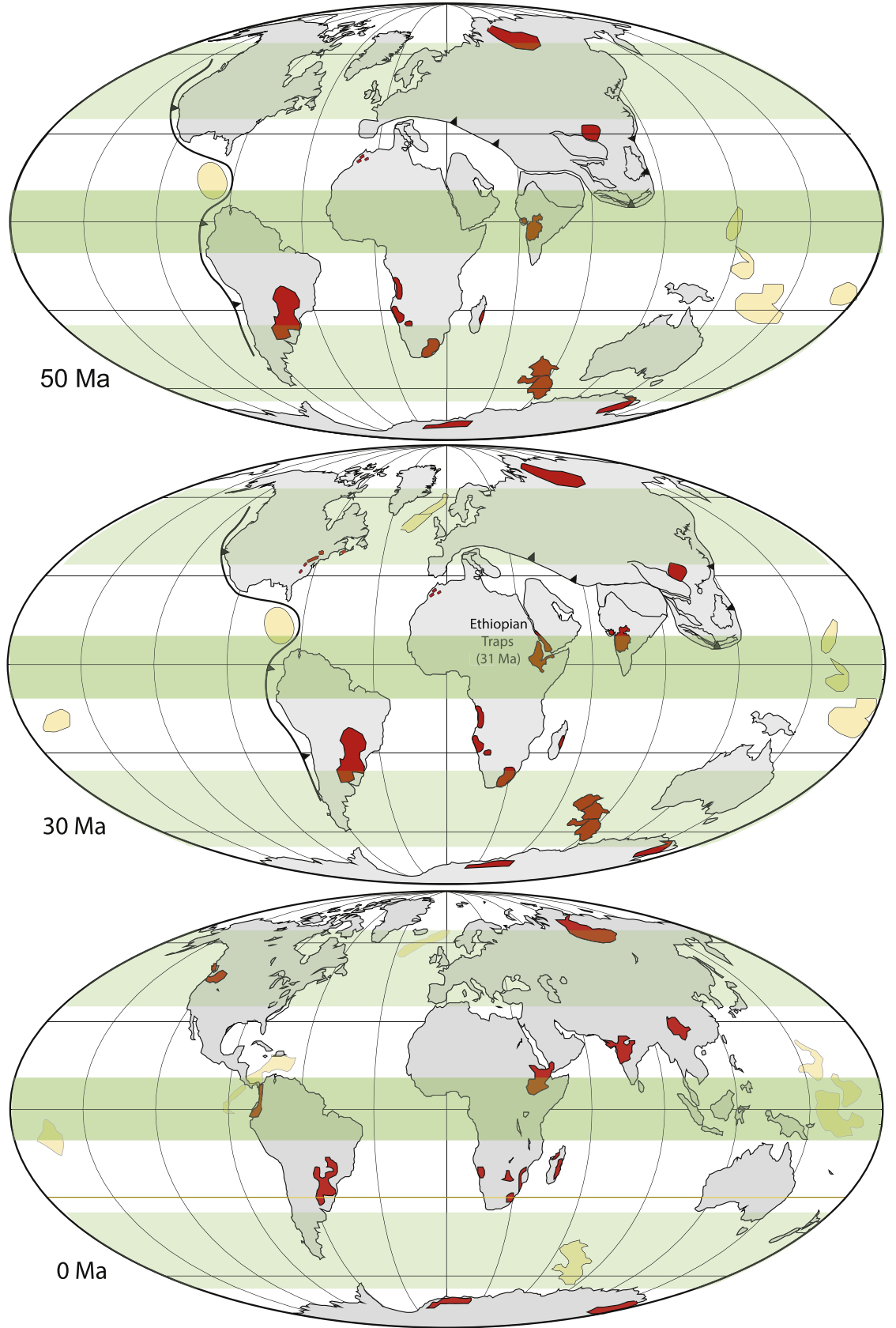


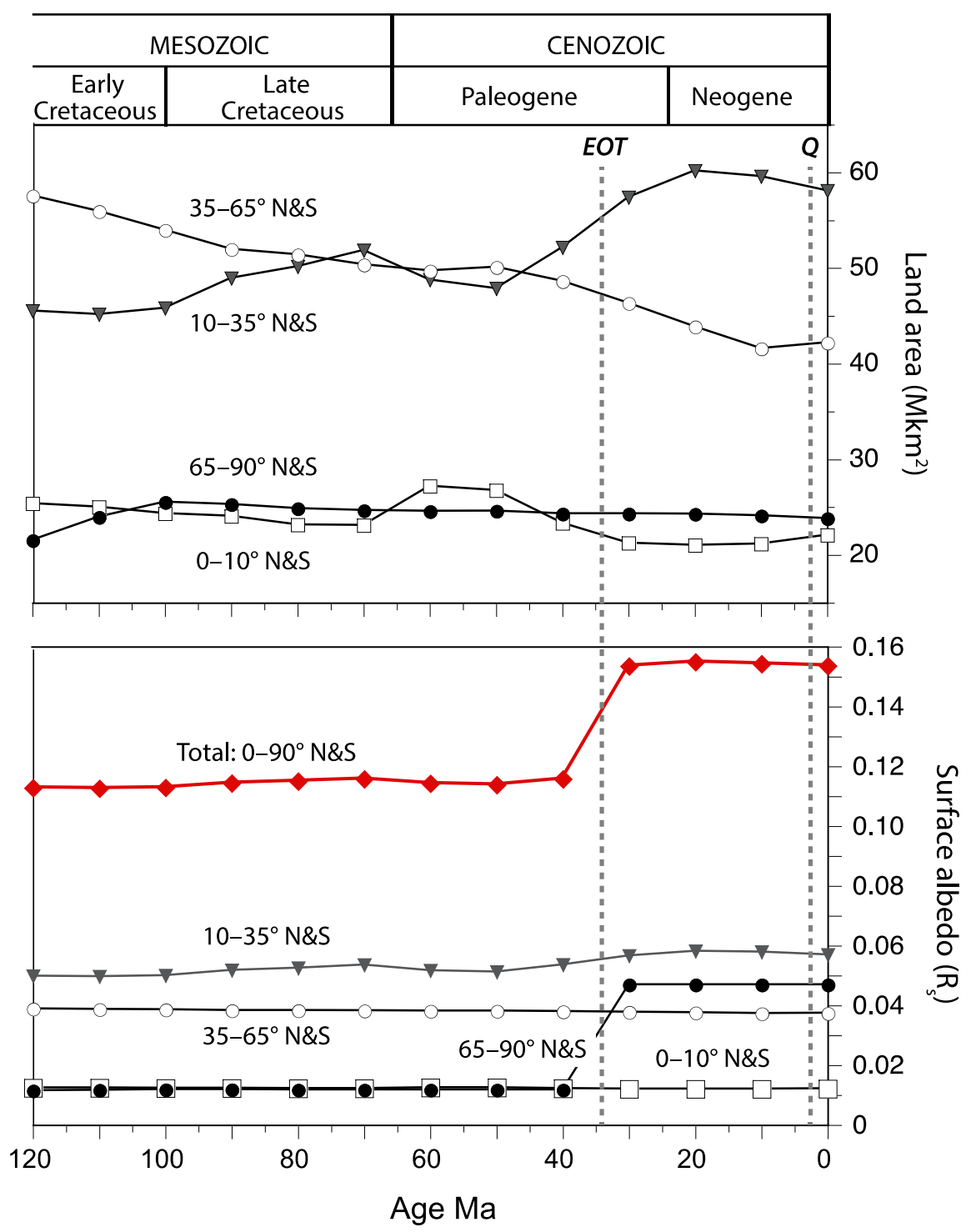

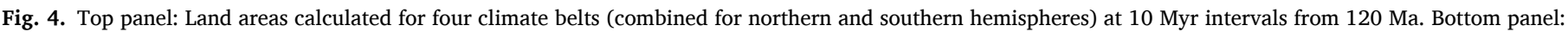

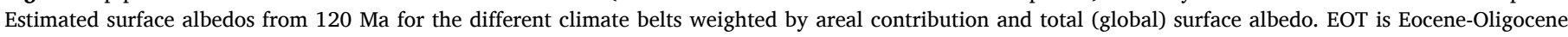
transition at $34 \mathrm{Ma}$; Q is beginning of Quaternary at 2.6 Ma.

\section{Results}

The overall motif for paleocontinental reconstructions since $120 \mathrm{Ma}$ (Fig. 3) is the dispersal of the continents to form the North and South Atlantic and the Indian Oceans with the reciprocal closure of the Tethys Ocean advanced by the rapid northward flight of Greater India (hereafter simply India) to collide with Asia at $50 \mathrm{Ma}$, a resulting southward tectonic extrusion of Southeast Asia and the ongoing closure with Australia-New Guinea. In terms of latitudinal changes in land areas, the major continental quartet of Asia, Africa, North America and South America played a relatively minor role over this 120 Ma to Present time interval because their relative motions were largely East-West. Instead, it was the northward motions of India and Australia-New Guinea and the southward tectonic extrusion of SE Asia that account for much of the latitudinal changes in land area of potential climatic significance. The question is which aspects of this tectonic development might have been related to significant junctures in climate history over this time period, such as the Cretaceous thermal maximum (CTM) at $90 \mathrm{Ma}$, the Early Eocene climate optimum (EECO) at $50 \mathrm{Ma}$, the Eocene-Oligocene Transition (EOT) at $34 \mathrm{Ma}$ and ensuing Late Cenozoic Ice Age to the
Present (Fig. 1).

The tropical humid $\left(0-10^{\circ} \mathrm{N} \& \mathrm{~S}\right)$ and polar $\left(65-90^{\circ} \mathrm{N} \& \mathrm{~S}\right)$ belts have comparable land areas with relatively modest changes since $120 \mathrm{Ma}$ (Fig. 4A, Table S1). The tropical humid belt has an overall $\sim 15 \%$ decrease in land area from 120 Ma to the Present due to the slow northward drift of the western bulge of Africa out of the tropical belt but punctuating this decreasing trend is a $\sim 15 \%$ boost in land area at 60 to $50 \mathrm{Ma}$ due to the northward transit of India through the tropics on its trajectory for collision with Asia at about $50 \mathrm{Ma}$ (Fig. 3B,C). In contrast, the land area trend in the polar belt is essentially flat after a $\sim 10 \%$ increase between $120 \mathrm{Ma}$ and $100 \mathrm{Ma}$ as the result of Antarctica becoming more centered on the South Pole. The largest secular changes in land area, both relative and absolute, are the decrease in the temperate $\left(35-65^{\circ} \mathrm{N} \& \mathrm{~S}\right)$ belt and the reciprocal increase in the semitropical arid $\left(10-35^{\circ} \mathrm{N} \& \mathrm{~S}\right)$ belt. The separation of India and later Australia-New Guinea from Antarctica and their northward drift from high southern latitudes are important elements that account for the decrease amounting to $\sim 15 \mathrm{Mkm}^{2}(\sim 26 \%)$ in land area in the temperate belt and a comparable but less regular increase of $\sim 14 \mathrm{Mkm}^{2}(\sim 30 \%)$ in the semitropical arid belt. 


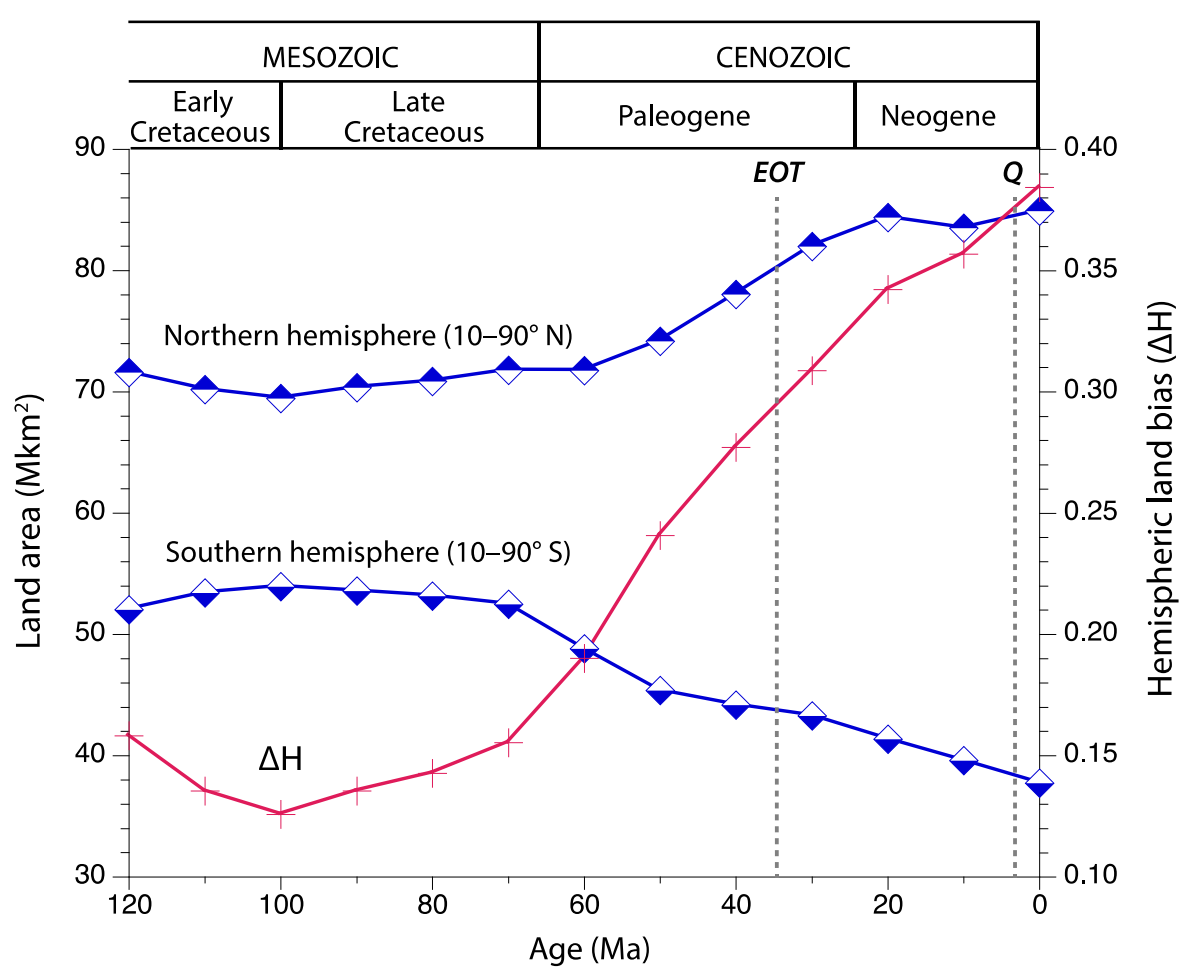

Fig. 5. Land areas between 10 and $90^{\circ}$ latitude in the northern and southern hemispheres estimated at 10 Myr intervals from 120 Ma (Table S1). Hemispheric land bias is gauged by the parameter, $\mathbf{\Delta} \mathbf{H}=$ $\left(\mathrm{NH}_{10: 90}-\mathrm{SH}_{10: 90}\right) /\left(\mathrm{NH}_{10: 90}+\mathrm{SH}_{10: 90}\right)$, where $\mathrm{NH}_{10: 90}$ and $\mathrm{SH}_{10: 90}$ are the land areas between 10 and $90^{\circ}$ latitude in respectively the northern $(\mathrm{NH})$ and southern $(\mathrm{SH})$ hemispheres. $\Delta \mathbf{H}$ can range from +1 for all land in these latitudinal belts in the northern hemisphere to -1 in the southern hemisphere, and is 0 for no hemisphere bias. EOT is Eocene-Oligocene transition at $34 \mathrm{Ma}$; $\mathrm{Q}$ is beginning of Quaternary at 2.6 Ma.
From the foregoing, we surmise that relative changes in contributions to global surface albedo since $120 \mathrm{Ma}$ are going to be relatively minor from the tropical humid belt given its relatively constant land area combined with the narrow range of expected surface albedos (Fig. 4B, Table S2). If the mean proportion of land $(\sim 0.27)$ is assumed to be tropical forest $\left(\mathrm{R}_{\mathrm{s}}=0.10\right)$ and averaged with the complementary proportion (0.73) of ocean $\left(R_{s}=0.06\right)$, the tropical humid belt would have an average surface albedo of only about 0.071 since $120 \mathrm{Ma}$. Weighted by its proportion (0.174) of Earth's surface area, the estimated albedo $\left(R_{s}=\right.$ 0.0124) of the tropical humid belt makes a small contribution to total global surface albedo (Fig. 4B). Going poleward, the subtropical arid and temperate belts, constituting about $40 \%$ and $33 \%$ of Earth's surface area, had substantial secular changes in land area. Although land area decreased by nearly $15 \mathrm{Mkm}^{2}$ in the temperate belt since $120 \mathrm{Ma}$ (Fig. 4A), the constricted range of surface albedo from ocean water $\left(R_{s}\right.$ ranging to only about 0.10 with lower solar zenith angles) to coniferous and deciduous forests $\left(R_{S}=0.15\right)$ limits the overall expression of changing land areas on surface albedo (Fig. 4B). The subtropical arid belt had almost a complementary increase in land area $\left(\sim 14 \mathrm{Mkm}^{2}\right)$ (Fig. 4A) compared to the temperate belt but because of the relatively large contrast in the surface albedo of desert land $\left(R_{S}=35\right)$ compared to ocean water with higher solar zenith $\left(R_{s}=0.06\right)$, there is a general secular increase in the area-weighted contribution to global surface albedo from around $R_{S}=$ 0.050 at 120 Ma to $R_{s}=0.057$ at $0 \mathrm{Ma}$ (Fig. 4B).

The polar regions as defined constitute the climate belt with smallest proportion of Earth's surface area ( $9.4 \%$ for $\left.65-90^{\circ} \mathrm{N} \& \mathrm{~S}\right)$ but can have a widely variable surface albedo depending on the presence or absence of highly reflective snow and ice cover on land and sea. Although the landto-sea ratio stays relatively constant $(0.5145 \pm 0.0105$ s.d.) since 100 $\mathrm{Ma}$, evidence from pre-Oligocene deposits indicates equable conditions with the general absence of permanent snow cover and sea ice in polar regions whereas after the Eocene the presence of ice rafting and other direct climate indicators point to the inception of Antarctic ice sheets and approximately coeval Arctic cooling at the EOT at $34 \mathrm{Ma}$ (DeConto et al., 2008). Accordingly, we assume a surface albedo $R_{s}=0.15$ (coniferous forests) for land areas and $R_{S}=0.10$ for ice-free oceans in polar regions prior to $34 \mathrm{Ma}$, for an average $R_{s}=0.124$ (Fig. 4B), which weighted by surface area makes a small contribution $\left(R_{s}=0.012\right)$ to global surface albedo. After $34 \mathrm{Ma}$, we assign polar regions a surface albedo $R_{s}=0.6$, which translates to a much larger weighted contribution of $R_{s}=0.056$ to global surface albedo.

The calculated surface albedo contributions in each bihemispheric climate belt weighted by its surface area are summed to determine a global surface albedo for each $10 \mathrm{Myr}$ time step (Fig. 4B). The global surface albedo thus estimated is remarkably steady from 120 to $40 \mathrm{Ma}$, with an average $R_{s} \sim 0.114$. However, a major change comes from imposing high surface albedo for snow and ice on land and sea in the polar belt at the $34 \mathrm{Ma}$ EOT, which registers as a stepwise increase in global surface albedo at $30 \mathrm{Ma}$ and younger that averages to $R_{s}=0.153$, a harbinger of the modern and more exactly measured global surface albedo of $R_{s}=0.15$ (Robock, 1980).

As for hemispheric land bias, our calculations show that there has been consistently more land area in the northern hemisphere than in the southern hemisphere since $120 \mathrm{Ma}$ (Fig. 5). In an attempt to quantify any trends, we use a simple hemispheric land bias parameter, $\mathbf{\Delta H}=$ $\left(\mathrm{NH}_{10: 90}-\mathrm{SH}_{10: 90}\right) /\left(\mathrm{NH}_{10: 90}+\mathrm{SH}_{10: 90}\right)$, where $\mathrm{NH}_{10: 90}$ and $\mathrm{SH}_{10: 90}$ are the land areas between 10 and $90^{\circ}$ latitude in respectively the northern $(\mathrm{NH})$ and southern $(\mathrm{SH})$ hemispheres, together constituting $83 \%$ of Earth's surface area while avoiding uncertainties in hemispheric assignment in the $10^{\circ} \mathrm{S}-10^{\circ} \mathrm{N}$ tropical belt. $\Delta \mathrm{H}$ can range from +1 for all land in these latitudinal belts in the northern hemisphere to -1 in the southern hemisphere, and $\mathbf{0}$ for no hemisphere bias. The bias parameter $\Delta \mathbf{H}$ hovers around 0.15 from 120 to $70 \mathrm{Ma}$ and then steadily increases largely due to the northward drift of India from the southern to northern hemisphere to around 0.38 by $0 \mathrm{Ma}$, reasonably compatible with a hemispheric bias of around 0.35 for all land masses today. Despite the large hemispheric difference in land-sea distribution (and associated surface albedo), the amount of solar energy reflected from each hemisphere today is essentially identical with cloudiness as the principal regulatory agent that maintains a steady state condition (Stephens et al., 2015). Presumably this regulatory mechanism was also operative in the past, in which case the increasing hemispheric land bias over the Cenozoic might provide clues with skilled modeling of the potential role of this elusive element of the radiation budget in long-term climate change. 
A

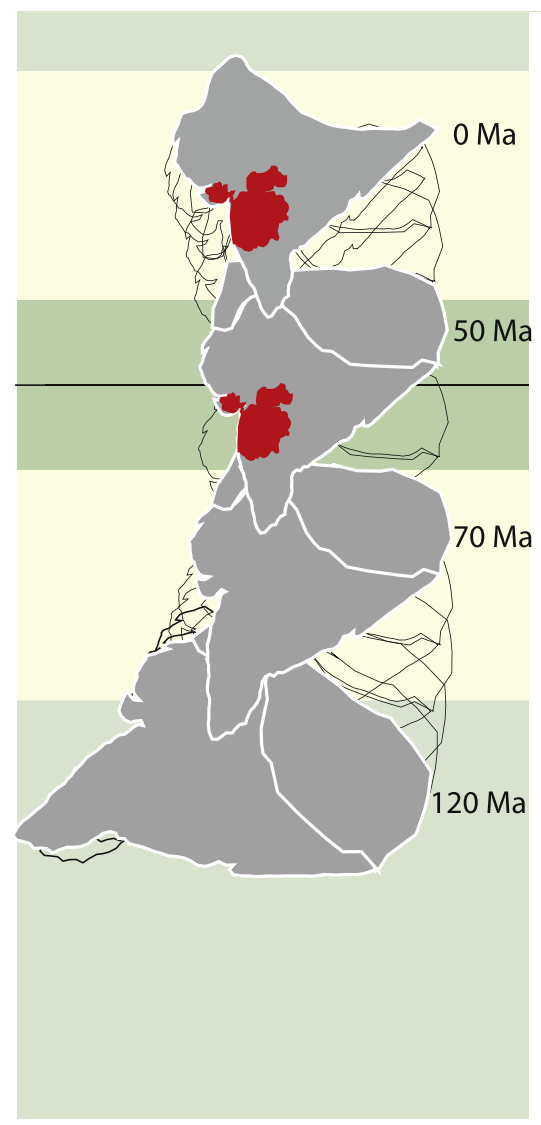

B

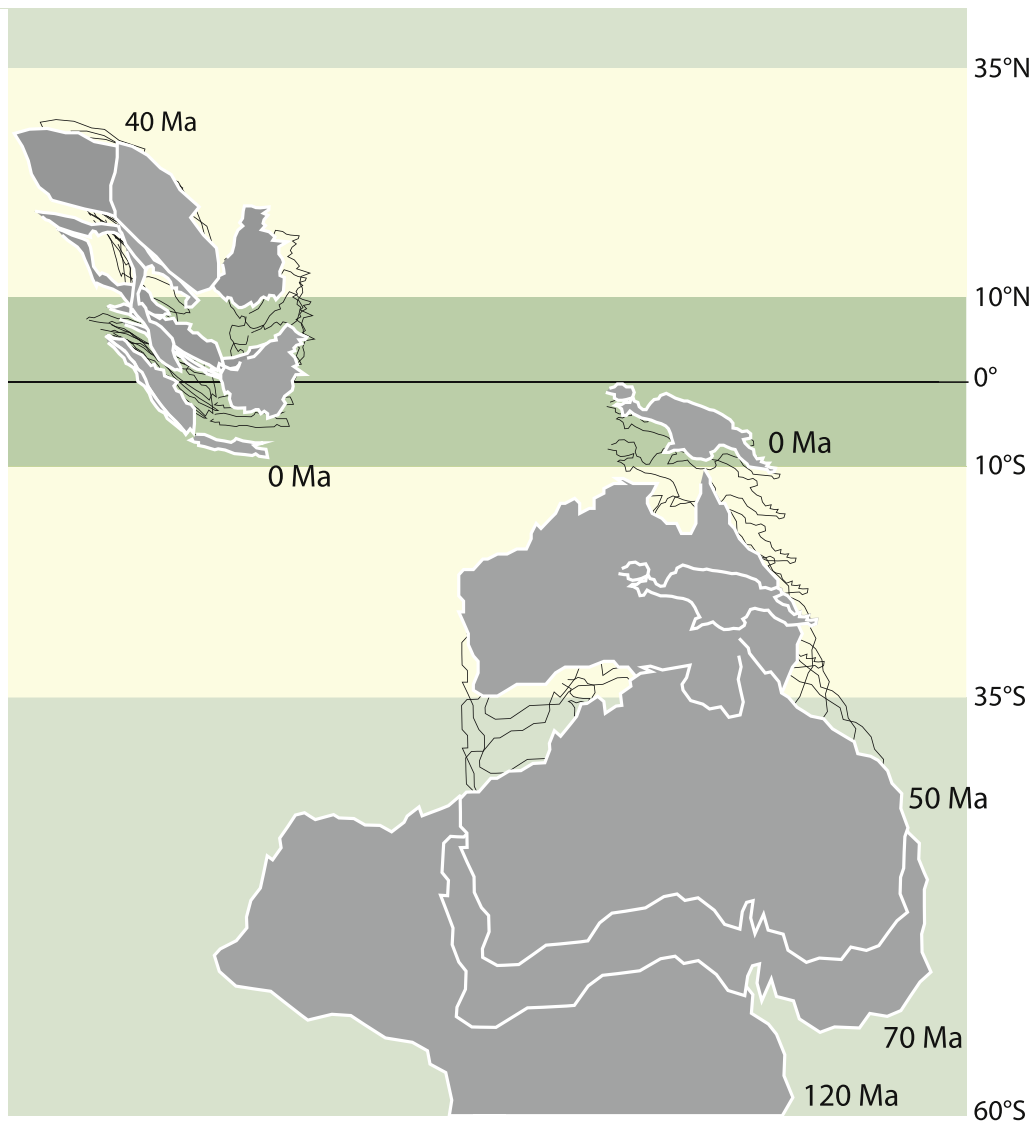

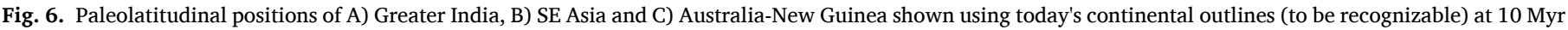

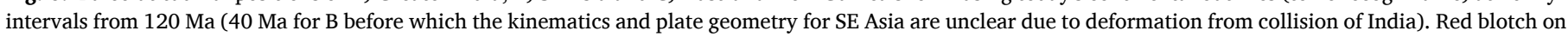

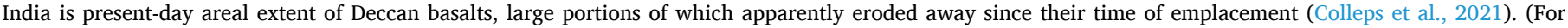
interpretation of the references to colour in this figure legend, the reader is referred to the web version of this article.)

\section{Discussion}

We find that global surface albedo was remarkably steady from 120 Ma until the onset of polar ice sheets at the EOT at $34 \mathrm{Ma}$ at only about $75 \%\left(R_{s}=0.114\right)$ of its value immediately after the EOT $\left(R_{s}=0.153\right)$. This shift to essentially the modern surface albedo is the most noteworthy feature in the entire surface albedo record we generated and is due to the appearance of reflective snow and ice in polar regions, as mandated by independent evidence from ice rafting and a step increase in continental ice volume inferred from sea level lowering and oxygen isotope analyses of benthic foraminifera (Fig. 1). There is no significant change in land area in any climate belt across the EOT and in particular, we find little overall change in land area in polar regions over practically the entire time span since $120 \mathrm{Ma}$ (Fig. 4). The high albedo in polar regions that was imposed at the EOT in our analysis can be attributed to a positive ice-albedo feedback in response to a lowered radiative balance from reduced $p \mathrm{CO}_{2}$ concentrations (DeConto and Pollard, 2003). A decline in atmospheric $p \mathrm{CO}_{2}$ concentration apparently drove global cooling from ECCO at $50 \mathrm{Ma}$ toward the onset of polar glaciation at the EOT at 34 Ma (Anagnostou et al., 2016; see also Gasson et al., 2014; Goldner et al., 2013).

Variations in atmospheric $p \mathrm{CO}_{2}$ concentrations have traditionally been modeled as a response to tectonic outgassing linked to global seafloor production rates (e.g., (Berner, 1990)). However, the observed area-age distribution of ocean floor does not call for any substantial changes in seafloor production since 180 Ma (Rowley, 2002, 2008) whereas even subduction of carbonate-rich sediments may be insufficient to markedly change long-term $\mathrm{CO}_{2}$ outgassing (Kent and Muttoni, 2013). Tectonic outgassing may thus have hardly varied from today's $\mathrm{CO}_{2}$ flux from mid-ocean ridges, subduction zones and mantle plumes (Marty and Tolstikhin, 1998) and our supposition therefore has been that variations in $\mathrm{CO}_{2}$ sinks from silicate weathering consumption (and organic carbon burial) presumably controlled atmospheric $p \mathrm{CO}_{2}$ concentrations on geologic time scales. Of particular importance is high $\mathrm{CO}_{2}$ consumption from intense weathering of alkaline $(\mathrm{CaO}+$ $\mathrm{MgO}-$ rich) silicate rocks as in continental basaltic provinces and obducted ophiolites from arc-continent collisions especially in the warm tropical humid belt (Dessert et al., 2003). In particular, passage of India with the Deccan Traps across the tropical humid belt (Kent and Muttoni, 2008, 2013) (Fig. 6A), which is responsible for the bump at 60-50 Ma in the land area plot for $0-10^{\circ} \mathrm{N} \& \mathrm{~S}$ (Fig. 4A), combined with contributions from weathering of obducted ophiolites from Tethyan arc-continent collisions in the broader tropics (Jagoutz et al., 2016; Macdonald et al., 2019), may have initiated and sustained the decline in atmospheric $p \mathrm{CO}_{2}$ levels and associated greenhouse temperatures that culminated with the onset of Antarctic glaciations at the EOT (34 Ma) with amplification from ice albedo feedback (DeConto and Pollard, 2003) and served to lock-in the Late Cenozoic Ice Age. Northern hemisphere glaciations later in the Neogene may been fostered by enhanced $\mathrm{CO}_{2}$ consumption in the most potent weathering region today: the Indonesia and Borneo areas of SE Asia plus New Guinea, high relief arc terranes that converged to straddle the tropical humid belt (Dessert et al., 2003; Kent and Muttoni, 2013; Park et al., 2020) (Fig. 6B).

Additional and ongoing global cooling may have resulted from 
increasing surface albedo with Australia's continued northward drift into the austral semitropical arid belt (Fig. 6C). Although the high surface albedo of desert land $\left(R_{S}=0.35\right)$ could be contributing to a cooling trend in the Cenozoic (Barron, 1985), there is a practical limit: if the $29 \%$ of Earth's surface area that is presently land was all in the arid belts with a surface albedo of $R_{s}=0.35$ (contribution to global surface albedo of $R_{s}=0.1015$ ), then combined with the $71 \%$ of Earth's surface area that is ocean with a surface albedo of $R_{s}=0.06$ (contribution to global surface albedo of $R_{S}=0.0426$ ) would result in a total global surface albedo of $R_{s}=0.144$. This is less than today's global surface albedo of $R_{S}$ $=0.15$ and however improbable the circumstance, places an upper limit to global surface albedo for times when there is essentially no evidence for polar ice, such as between 120 and $40 \mathrm{Ma}$.

But clouds typically get in the way of comprehensive climate models. Cloud cover effectively doubles today's albedo from its surface value of $R_{s}=0.15$ to a total planetary value of $R_{p}=0.29$. Cloud albedo feedbacks have large uncertainty (Goldner et al., 2013) and there is no proxy of clouds in the geologic record, hence planetary albedo is often set as a constant in climate models (e.g., Foster et al., 2017). However, given the measurable shift in global surface albedo from pre-EOT (nonglacial) to post-EOT (glacial) worlds, setting total planetary albedo as fixed to the present value may limit analytical capabilities of climate models; for example, climate sensitivity may be quite different in low compared to high global surface albedo worlds (Hansen et al., 2008). The markedly increasing hemispheric land bias over the Cenozoic also implies an increasing role of cloudiness to regulate a radiative balance between northern and southern hemispheres over the Cenozoic.

\section{Conclusions}

Our analysis suggests that the two smallest and most opposite climate belts - the tropical humid and polar belts - work in tandem to underwrite whether global climate is glacial or nonglacial. The perennially warm and humid tropical belt may have relatively small impact on albedo but is the optimal venue for intense weathering consumption of $\mathrm{CO}_{2}$, especially of alkaline-rich continental and arc rocks that occasionally drift through and/or emerge there, such as the Deccan and Ethiopian Traps and SE Asia in the Cenozoic. The cool to cold polar regions have negligible impact on weathering consumption of $\mathrm{CO}_{2}$ but are the venue for highly reflective ice and snow, which during occasional times of sustained low $p \mathrm{CO}_{2}$ from especially high weathering consumption in the warm tropical humid belt can amplify greenhouse cooling by ice albedo feedback. Assuming that the planetary albedo is proportional in some way to global surface albedo, the coincidence of high $\mathrm{CO}_{2}$ weathering consumption in the tropical humid belt and ice albedo feedback in the polar belt can lock Earth's climate in an ice age mode, released only when $p \mathrm{CO}_{2}$ regains sufficiently high values from reduced weathering consumption to turn off the ice albedo feedback.

Supplementary data to this article can be found online at https://doi. org/10.1016/j.palaeo.2021.110718.

\section{Declaration of competing interest}

The authors declare no conflicts of interest.

\section{Acknowledgements}

We appreciate the exchanges with Linda Sohl that were very helpful in clarifying aspects of paleoclimate modeling and critical comments from Francis Macdonald and the other journal reviewer that helped us to incorporate a more expanded view of climate belts. DK thanks the Paleomagnetic Research Fund at Lamont-Doherty Earth Observatory, Board of Governor Discretionary Fund at Rutgers University, and with GM the University of Milan for support of this research.

\section{References}

Anagnostou, E., John, E.H., Edgar, K.M., Foster, G.L., Ridgwell, A., Inglis, G.N., Pancost, R.D., Lunt, D.J., Pearson, P.N., 2016. Changing atmospheric CO2 concentration was the primary driver of early Cenozoic climate. Nature 533, 380-384.

Barron, E.J., 1985. Explanations of the Tertiary global cooling trend. Palaeogeogr. Palaeoclimatol. Palaeoecol. 50, 45-61.

Barron, E.J., Sloan, J.L., Harrison, C.G.A., 1980. Potential significance of land-sea distribution and surface albedo variations as a climatic forcing factor; $180 \mathrm{~m}$.y. to the present. Palaeogeogr. Palaeoclimatol. Palaeoecol. 30, 17-40.

Berner, R.A., 1990. Atmospheric carbon dioxide levels over Phanerozoic time. Science 249, 1382-1386.

Berner, R.A., 1991. A model for atmospheric CO2 over Phanerozoic time. Am. J. Sci. 291, 339-376.

Berner, R.A., 1994. GEOCARB II: a revised model of atmospheric CO2 over Phanerozoic time. Am. J. Sci. 294, 56-91.

Berner, R.A., 2006. GEOCARBSULF: a combined model for Phanerozoic atmospheric O2 and CO2. Geochim. Cosmochim. Acta 70, 5653-5664.

Berner, R.A., Kothalava, Z., 2001. GEOCARB III: a revised model of atmospheric CO2 over Phanerozoic time. Am. J. Sci. 301, 182-204.

Berner, R.A., Lasaga, A.C., Garrels, R.M., 1983. The carbonate-silicate geochemical cycle and its effect on atmospheric carbon dioxide over the past 100 million years. Am. J. Sci. 283, 641-683.

Burls, N.J., Fedorov, A.V., 2017. Wetter subtropics in a warmer world: Contrasting past and future hydrological cycles. Proc. Natl. Acad. Sci. 114 (49), 12888.

Cogné, J.P., 2003. PaleoMac: A Macintosh ${ }^{\mathrm{TM}}$ application for treating paleomagnetic data and making plate reconstructions. Geochem. Geophys. Geosyst. 4, 1007. https://doi. org/10.1029/2001GC000227.

Colleps, C.L., McKenzie, N.R., Guenthner, W.R., Sharma, M., Gibson, T.M., Stockli, D.F., 2021. Apatite (U-Th)/he thermochronometric constraints on the northern extent of the Deccan large igneous province. Earth Planet. Sci. Lett. 571, 117087.

Cramer, B.S., Miller, K.G., Toggweiler, J.R., Barrett, P.J., Wright, J.D., 2011. Late Cretaceous-Neogene trends in deep ocean temperature and continental ice volume: reconciling records of benthic foraminiferal geochemistry ( $\delta 180$ and $\mathrm{Mg} / \mathrm{Ca}$ ) with sea level history. J. Geophys. Res. Oceans 116, C12023. https://doi.org/10.11029/ 12011JC007255.

Crowley, T.J., Berner, R.A., 2001. CO2 and climate change. Science 292, 870-872.

DeConto, R.M., Pollard, D., 2003. Rapid cenozoic glaciation of Antarctica induced by declining atmospheric CO2. Nature 421, 245-249.

DeConto, R.M., Pollard, D., Wilson, P.A., Palike, H., Lear, C.H., Pagani, M., 2008. Thresholds for Cenozoic bipolar glaciation. Nature 455, 652-656.

Dessert, C., Dupré, B., Gaillardet, J., Francois, L., Allègre, C., 2003. Basalt weathering laws and the impact of basalt weathering on the global carbon cycle. Chem. Geol. 202, 257-273.

Donnadieu, Y., Godderis, Y., Ramstein, G., Nedelec, A., Meert, J., 2004. A 'snowball Earth' climate triggered by continental break-up through changes in runoff. Nature 428, 303-306.

Donnadieu, Y., Pierrehumbert, R., Jacob, R., Fluteau, F., 2006. Modelling the primary control of paleogeography on Cretaceous climate. Earth Planet. Sci. Lett. 248, 426-437.

Eberle, J.J., Greenwood, D.R., 2012. Life at the top of the greenhouse Eocene world- a review of the Eocene flora and vertebrate fauna from Canada's High Arctic. Geol. Soc. Am. Bull. 124, 3-23.

Eldrett, J.S., Harding, I.C., Wilson, P.A., Butler, E., Roberts, A.P., 2007. Continental ice in Greenland during the Eocene and Oligocene. Nature 446, 176-179.

Feulner, G., 2012. The faint young Sun problem. Rev. Geophys. 50 https://doi.org/ 10.1029/2011RG000375.

Foster, G.L., Royer, D.L., Lunt, D.J., 2017. Future climate forcing potentially without precedent in the last 420 million years. Nat. Commun. 8, 14845.

Gasson, E., Lunt, D.J., DeConto, R., Goldner, A., Heinemann, M., Huber, M., LeGrande, A. N., Pollard, D., Sagoo, N., Siddall, M., Winguth, A., Valdes, P.J., 2014. Uncertainties in the modelled CO2 threshold for Antarctic glaciation. Clim. Past 10, 451-466.

Goddéris, Y., Donnadieu, Y., de Vargas, C., Pierrehumbert, R.T., Dromart, G., van de Schootbrugge, B., 2008. Causal or casual link between the rise of nannoplankton calcification and a tectonically-driven massive decrease in Late Triassic atmospheric CO2? Earth Planet. Sci. Lett. 267, 247-255.

Goddéris, Y., Donnadieu, Y., Hir, G.L., Lefebvre, V., Nardin, E., 2014. The role of palaeogeography in the Phanerozoic history of atmospheric CO2 and climate. Earth Sci. Rev. 128, 122-138.

Goldner, A., Huber, M., Caballero, R., 2013. Does Antarctic glaciation cool the world? Clim. Past 9, 173-189. https://doi.org/10.5194/cp-5199-5173-2013.

Hansen, J., Sato, M., Kharecha, P., Beerling, D., Berner, R., Masson-Delmotte, V., Pagani, M., Raymo, M., Royer, D.L., Zachos, J.C., 2008. Target atmospheric CO2: where should humanity aim? Open Atmos. Sci. J. 2, 217-231.

Hansen, J., Sato, M., Russell, G., Kharecha, P., 2013. Climate sensitivity, sea level and atmospheric carbon dioxide. Philos. Trans. R. Soc. A Math. Phys. Eng. Sci. 371, 20120294.

Henderson-Sellers, A., Wilson, M.F., 1983. Surface albedo data for climatic modeling. Rev. Geophys. 21, 1743-1778.

Hoffman, P.F., Schrag, D.P., 2002. The snowball Earth hypothesis: testing the limits of global change. Terra Nova 14, 129-155.

Jagniecki, E.A., Lowenstein, T.K., Jenkins, D.M., Demicco, R.V., 2015. Eocene atmospheric CO2 from the nahcolite proxy. Geology 43, 1075-1078.

Jagoutz, O., Macdonald, F.A., Royden, L., 2016. Low-latitude arc-continent collision as a driver for global cooling. Proc. Natl. Acad. Sci. 113, 4935-4940. 
Katz, M.E., Miller, K.G., Wright, J.D., Wade, B.S., Browning, J.V., Cramer, B.S., Rosenthal, Y., 2008. Stepwise transition from the Eocene greenhouse to the Oligocene icehouse. Nat. Geosci. 1, 329-334.

Kennett, J.P., 1977. Cenozoic evolution of Antarctic glaciation, the circum-antarctic ocean and their impact on global paleoceanography. J. Geophys. Res. 82, 3843-3860.

Kent, D.V., Muttoni, G., 2008. Equatorial convergence of India and early Cenozoic climate trends. Proc. Natl. Acad. Sci. 105, 16065-16070.

Kent, D.V., Muttoni, G., 2013. Modulation of Late Cretaceous and Cenozoic climate by variable drawdown of atmospheric pCO2 from weathering of basaltic provinces on continents drifting through the equatorial humid belt. Clim. Past 9, 525-546.

Kukla, G., Robinson, D., 1980. Annual cycle of surface albedo. Mon. Weather Rev. 108, 56-68.

Lacis, A.A., Schmidt, G.A., Rind, D., Ruedy, R.A., 2010. Atmospheric CO2: principal control knob governing Earth's temperature. Science 330, 356-359.

Liu, Z., Pagani, M., Zinniker, D., DeConto, R., Huber, M., Brinkhuis, H., Shah, S.R., Leckie, R.M., Pearson, A., 2009. Global cooling during the Eocene-Oligocene climate transition. Science 323, 1187-1190.

Macdonald, F.A., Swanson-Hysell, N.L., Park, Y., Lisiecki, L., Jagoutz, O., 2019. Arc continent collisions in the tropics set Earth's climate state. Science 364, 181.

Manabe, S., Bryan, K., 1985. CO2-induced change in a coupled ocean-atmosphere model and its paleoclimatic implications. J. Geophys. Res. 90, 11689-11707.

Marty, B., Tolstikhin, I.N., 1998. CO2 fluxes from mid-ocean ridges, arcs and plumes. Chem. Geol. 145, 233-248.

Opdyke, N.D., Kent, D.V., Foster, D.A., Huang, K., 2015. Paleomagnetism of Miocene volcanics on Sao Tome: Paleosecular variation at the Equator and a comparison to its latitudinal dependence over the last 5 Myr. Geochem. Geophys. Geosyst. 16, 3870-3882.

Pagani, M., Huber, M., Liu, Z., Bohaty, S.M., Henderiks, J., Sijp, W., Krishnan, S., DeConto, R.M., 2011. The role of carbon dioxide during the onset of Antarctic glaciation. Science 334, 1261-1264.

PALAEOSENS, 2012. Making sense of palaeoclimate sensitivity. Nature 491, 683-691.
Park, Y., Maffre, P., Goddéris, Y., Macdonald, F.A., Anttila, E.S.C., Swanson-Hysell, N.L., 2020. Emergence of the Southeast Asian islands as a driver for Neogene cooling. Proc. Natl. Acad. Sci. 202011033.

Peel, M.C., Finlayson, B.L., McMahon, T.A., 2007. Updated world map of the KöppenGeiger climate classification. Hydrol. Earth Syst. Sci. 11, 1633-1644.

Pross, J., Contreras, L., Bijl, P.K., Greenwood, D.R., Bohaty, S.M., Schouten, S., Bendle, J. A., Rohl, U., Tauxe, L., Raine, J.I., Huck, C.E., van de Flierdt, T., Jamieson, S.S.R., Stickley, C.E., van de Schootbrugge, B., Escutia, C., Brinkhuis, H., 2012. Persistent near-tropical warmth on the Antarctic continent during the early Eocene epoch. Nature 488, 73-77.

Robock, A., 1980. The seasonal cycle of snow cover, sea ice and surface albedo. Mon. Weather Rev. 108, 267-285.

Rowley, D.B., 2002. Rate of plate creation and destruction: 180 Ma to present. Geol. Soc. Am. Bull. 114, 927-933.

Rowley, D.B., 2008. Extrapolating oceanic age distributions: lessons from the Pacific region. J. Geol. 116, 587-598.

Royer, D.L., 2014. Atmospheric CO2 and O2 during the Phanerozoic: tools, patterns, and impacts. In: Holland, H., Turekian, K.K. (Eds.), Treatise on Geochemistry. Elsevier, Amsterdam, pp. 251-267.

Stephens, G.L., O’Brien, D., Webster, P.J., Pilewski, P., Kato, S., Li, J.-L., 2015. The albedo of Earth. Rev. Geophys. 53, 141-163. https://doi.org/10.1002/ 2014RG000449.

Tauxe, L., 2005. Inclination flattening and the geocentric axial dipole hypothesis. Earth Planet. Sci. Lett. 233, 247-261.

Thompson, S.L., Barron, E.J., 1981. Comparison of Cretaceous and present Earth albedos: implications for the causes of paleoclimates. J. Geol. 89, 143-167.

Tibbett, E.J., Scher, H.D., Warny, S., Tierney, J.E., Passchier, S., Feakins, S.J., 2021. Late Eocene record of hydrology and temperature from Prydz Bay, East Antarctica. Paleoceanogr. Paleoclimatol. 36 e2020PA004204.

Walker, J.C.G., Hays, P.B., Kasting, J.F., 1981. A negative feedback mechanism for the long-term stabilization of Earth's surface-temperature. J. Geophys. Res.-Atmos. 86, 9776-9782. 